REFLECTIONS:

NEUROLOGY AND

THE HUMANITIES

Section Editor

Anne W. McCammon,

MD, FAAN

\title{
Godless State
}

November 22, 2013:

"Jonesy," I say. "It's Dr. Braunstein. He’s here to see you."

"Hello, Mr. Jones. Dr. Joseph Michael Braunstein

Correspondence to Dr. Warnack:

worthy.warnack@utsouthwestern. edu eyes closed, your body motionless. "Open your eyes," here." Towering over your bed, he gazes at you, your he says. Nothing happens. He raises your left eyelid and says, "Look over here at me." Your eye does not move. With his free hand he wriggles his fingers while slowly moving his hand from side to side, and your eye does not pursue his moving hand. "Close your eyes," he says, and he feels no pressure on the finger that holds your left eyelid open. He brings his free hand down rapidly towards your left eye, and you do not blink. He says, "Show me two fingers with your right hand," and you remain motionless. He says, "Wriggle your fingers," and nothing happens. "Wriggle your toes," and no movement. He presses his fist into your sternum and nothing happens.

I recall Braunstein's intensive care unit examinations. "If you start twisting his nipple, Doctor, I swear I'm going to walk you to the door."

"No, of course not," Braunstein replies. He pauses, in contemplation, then commands, "Mr. Jones, imagine you are playing a game of tennis."

"He doesn't play tennis, Doctor," I say. (What does he expect you to do-stand up and recite the Gettysburg address?)

"Ms. Appelfeld," he says, "What question was it that caused such clear functional MRI activation?"

"Are you asking me?" (Functional MRI. Like I know what a functional MRI is.)

"I remember," Braunstein says. "It was the house walk through question. Lena, on what street did the two of you live together?"

"Marquette Street," I say.

Dr. Braunstein leans over and speaks clearly and authoritatively into your left ear, "Mr. Jones, imagine you are walking through every room of your house on Marquette, starting at the front door."

You retrieve the Dallas Morning News from the driveway and walk past the "Ron Kirk for Mayor" sign in the front yard on the way to your front door. You are locked out. You ring the doorbell. Lena opens the door and glares at you. You step inside, standing on the colorful Turkish rug you and Lena bought together in Istanbul. You take 3 steps forward, stop, and face left. You see the dining room, the big bay windows to the left. You see yourself seated at the end of the long table, the bay windows at your back. Lena's father sits at the head of the table, nearest the kitchen. A short, bald man, he looks intently at Sarah, his eyes big and magnified by thick oversized black glasses. Sarah sits to your left. She asks why this night is different from all other nights. With his eastern European accent, $M r$. Appelfeld answers. He talks about a people in slavery who find their freedom. A large plate bearing horseradish, romaine lettuce, charoset, parsley, a roasted lamb bone, and a hard-boiled egg sits upon the beautifully set tabletop. You wait for the next sip of wine. Lena sits to her father's left. Three others are seated. You are calm and content.

"You know he thinks, Doctor, but you have no idea what he's thinking," I say. "He could be in hell for all you know."

You remain in the entrance hall and turn around now, face the opposite direction, and look into the formal living room, big bay windows to the right. You see yourself seated on a long white couch facing the bay windows. Sarah half-sits, half-stands to your right, excitedly inspecting eight wrapped gifts of varying sizes and shapes spread out on a large flat off-green coffee tabletop. A large menorah on the tabletop, the shamash and the candle on the far right burning. Lena, a glass of red wine in her hand, sits in a chair, watching Sarah; the flickering candlelight illuminates Lena's beautiful, smiling face. Her father sits in a chair to her right. There are others in the room. You are stuffed with latkes, applesauce, gefilte fish, and matzo ball soup, working on your dreidel spin technique on the tabletop. You are calm and content.

Dr. Braunstein proclaims, "Lena, in my opinion, Mr. Jones has a rich inner life. All our testing has shown this."

"A rich inner life?" I say. "That may well be true. I don't doubt it. It's his outer life I deal with, Doctor, and you haven't been wiping his ass for the last 5 months."

"Ms. Appelfeld, please, there's no need for language like that." 
You take three more steps forward in the entrance hall. Stairs to the left; to the right hang two of your paintings from your Austin days, from the Psilocybin series: Hope Springs Barton and Erection at Hippie Hollow (The Horror). You continue forward. To the left, the kitchen; you take a few steps in and your feet feel the ridges in the water damaged wooden floor, and you look through the small kitchen window to the backyard and the once used grill. You walk out of the kitchen and into the den, to your cherished book collection and the Spanish wood painting that hangs above the never used fireplace. You walk back into the entrance hall and climb the stairs. To the left, Sarah's bedroom with its open windows facing down onto Marquette Street. To the right of Sarah's bedroom, Sarah's study. Sarah is there, in a comfortable cotton neck to toes nightgown. She sits in a chair before an antique computer screen. Her spine curves forward, away from the back rest. Her head is upright, her chin rests upon her knees, her knees up against her chest, her feet on the edge of her seat. Her arms hang limply by her sides, her elbows are bent, and her wrists rest on the front edge of the table. Her long, thin, ebony fingers work away at the keyboard, barely perceptible rapid clicking sounds of the keys as she writes, her eyes glued to the screen. To her right, her orange and white cat sprawls on an open book, its tail making carefree lazy choreiform movements, its eyes fixed upon Sarah's lovely face. A low, soft purring sound.

As if on cue, an all too familiar stench wafts nosewards from your bedside. That I am embarrassed, in the presence of Dr. Joseph Michael Braunstein, by your fecal incontinence, angers me; what that pompous neurosurgeon says next infuriates me, but I show no outward sign of emotion.

"You've got some work to do down there," he says, his nose wrinkled, his index finger pointing to your midsection.

In what was once the living room of our tiny one bedroom apartment, it's all right there, at your bedside-everything I need: the disposable rubber gloves (which I now don), the diapers (the dirty one that I remove, the new diaper that I struggle into place), the alcohol saturated soft hand towels, the gowns (yours, fortunately, does not need changing), the hermetically sealed trash can at the foot of the bed (into which I place the dirty diaper, the soiled alcohol saturated soft hand towels, and the disposable gloves), and the room deodorizer. Done! Diaper change in 1 minute 3 seconds. The smell of air freshener (lavender vanilla) and rubbing alcohol.

"Is there anything I can do to help?" Braunstein asks.

(Now he asks!)

Your left arm is at your side, flexed at the elbow and tight against your chest, your left wrist in flexion, your fingers in a sweaty, useless little ball; your left leg stiff and straight at the knee, ankle bent downwards in perfect diving toe point position. Your head is shaved. There is a long, crude scar shaped like an inverted Nike swoosh that covers the entire right side of your head. I stare at your enucleated right eye socket, your eyelids sewn together like an Amazonian shrunken head.

"No," I say, “you've already done quite enough. Thank you."

I have no one to help me with this. Sarah, somewhere in a frozen Ivy League landscape of granite and green, is lost to me. She has her own considerable problems to deal with.

You walk into the upstairs master bedroom and open the antique armoire at the foot of the bed, where the television sits upon a shelf; you find the remote and turn on the television. You are watching CNBC. On the screen you see smoke near the top of one of the World Trade Center towers. The broadcasters don't know exactly what has happened. They speculate that a private aircraft may have accidentally struck the tower. A helicopter circles. The smoke seems contained and no flames are visible and the situation does not look all that serious to you. Then you see a large aircraft strike the other tower, live, in real time. An orange ball of flame. You see it replayed. That was a commercial jet airliner that struck the tower. The broadcasters speak now of possible acts of terror. You stand facing the screen, motionless and transfixed. You see the towers collapse, one after the other. You do not think such a thing is possible. You continue to watch, thinking something else must be about to happen, but that is all there is.

"Lena," Dr. Braunstein says, "we must respect the sanctity of the life of the mind, in all of its manifestations."

Artificial nutrition and hydration: I consider the bag containing the thick yellow fluid, draining slowly into the feeding tube in your left side, just below your ribs; the intravenous fluids, flowing at $100 \mathrm{~mL}$ per hour into your right antecubital fossa. The frequent turning, the inspection of bony prominences for signs of skin breakdown, the sponge baths, the linen changes, the head shaves, the enucleated eye caremy daily routine for the last 5 months since your Parkland Hospital release. The digital blood pressure kit, the oxygen saturation monitor, the flotation mattress, the sequential compression devices, the condom catheter that will not stay on. The tracheostomy tube, the suction kit, the gentle, steady, sucking sound of our life savings, spiraling slowly down the drain.

"Lena, are you listening to me? I tell you," Dr. Braunstein says, "Mr. Jones is conscious."

"He's neither conscious nor unconscious, Doctor," I say. "He's in some godless state in between."

You are in the large room connected to the master bedroom now - the room that is your artist's studio. 
There is an office within the studio, and there you sita tall black man with an exuberant Afro, at a small desk under a fluorescent lamp-and you struggle with a crude battery-operated calculator, unable to make the figures do what they must do if you, Lena, and Sarah are to stay in that house. You stand, facing a huge empty canvas mounted upon a heavy easel. You stare at the white canvas for minutes, then hours, until finally, darkness fall; not one brushstroke, not a single good idea. You sulk into the master bedroom where Lena lies, eyes closed, feigning sleep. You undress completely, in darkness and in silence. You are lying on your back in bed, next to the woman you love, and you are thinking you were homeless every night you slept in that house.

I study Braunstein's face, as he resigns himself to the inevitable. I separate the feeding tube from your thin body, I stop the flow of intravenous fluids, and I cry like a little girl. 


\title{
Neurology
}

\author{
Godless State \\ Worthy R. Warnack \\ Neurology 2017;88;e196-e198 \\ DOI 10.1212/WNL.0000000000003953
}

This information is current as of May 22, 2017

\section{Updated Information \&} Services

Permissions \& Licensing

\section{Reprints}

including high resolution figures, can be found at: http://n.neurology.org/content/88/21/e196.full

Information about reproducing this article in parts (figures,tables) or in its entirety can be found online at:

http://www.neurology.org/about/about_the_journal\#permissions

Information about ordering reprints can be found online:

http://n.neurology.org/subscribers/advertise

Neurology ${ }^{\circledR}$ is the official journal of the American Academy of Neurology. Published continuously since 1951 , it is now a weekly with 48 issues per year. Copyright @ 2017 American Academy of Neurology. All rights reserved. Print ISSN: 0028-3878. Online ISSN: 1526-632X.

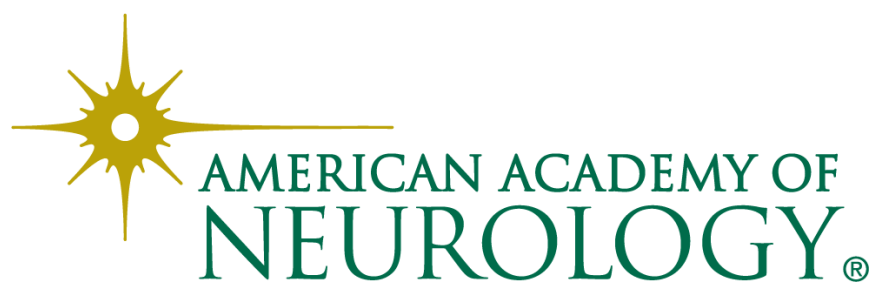

